\title{
G. F. Miller (Müller) — the First Archaeologist in Russia and the First Rector of Saint Petersburg University
}

\section{Igor Tikhonov}

University History Museum

St. Petersburg State University

Universitetskaja nab.7/9

St. Petersburg 199034, Russia

E-mail: I.Tikhonov@spbu.ru

\begin{abstract}
Gerhard Friedrich Miller (Müller) was a graduate of the University of Leipzig. In November 1725 he arrived in Russia, where he spent the rest of his life-first as an adjunct, then as a professor and a conference secretary of the Academy of Sciences. Since 1732 he published Sammlung Russischer Geschichte - the first Russian periodical publication on history. During a decade-long expedition to Southern Siberia, Miller worked out instructions for the study of archaeological sites and the classification of barrows. Miller was one of the first to realize the historical significance of archaeological sites and claimed that the main goal in the study of antiquities is to explain the ancient history of the inhabitants of the territory. Miller's activity was connected with the formation of a truly scientific approach to the antiquities. He was the first to write scientific works in Russian specifically devoted to the antiquities, which makes him the first Russian archaeologist.

In 1747, the President of St. Petersburg Academy of Sciences appointed Miller rector of the university. As a rector, he composed a catalogue of lectures, introduced required additional training in geography and arithmetic, and promoted teaching of foreign languages (French and German). For teaching the German language, he invited his brother to Russia. He made up chronological tables on history for students. Besides that, Miller prepared a draft of the new university regulations "following the example of European universities". The project provided autonomy, the right to award academic degrees and improved the social status of professors. However, this draft was not adopted.
\end{abstract}


Miller was serious about his responsibilities and took care of the students, trying to supply them with the necessary books and teaching aids, and incentives for the best students. He paid much attention to students' discipline and developed a system of penalties for misconduct. Most of the students who graduated the University at that time were left to work at the Academy of Sciences. In 1750, Miller was dismissed from the post of the rector. One of the reasons was his conflict with $M$. V. Lomonosov and the director of the Academy, G. N. Teplov.

Key words: archaeology, Miller (Müller), rector, Siberia, St. Petersburg University

\section{Introduction}

Gerhard Friedrich Miller (Müller in German) (1705-1783) was born in Herford in Germany. In November 1725, a 21-year graduate of the University of Leipzig arrived in Russia, where he spent the rest of his life. He learnt the Russian language, took Russian citizenship, and we can consider him a Russian scientist of German origin. First an associate, then a professor and a conference secretary of the Academy of Sciences, since 1732 he published Sammlung Russischer Geschichte (Müller, 1732-1764), the first periodical publication on Russian history. Miller's activity was very comprehensive and diversified: he was a historian, geographer, ethnographer, archivist, and journalist. Many works have been devoted to Miller's scientific activity and biography, including collections of articles (Dalmann \& Smagina, 2007) and monographs (Elett, 1996), as well as works in English (Black, 1986; Vermeulen, 2018) and in German (Hoffmann, 2005). The scientific community in Russia and Germany widely celebrated his 300th anniversary in 2005. I would like to focus only on two aspects of his work-archaeological research and directorship of the first Russian university. Especially since these aspects have not been sufficiently covered in the literature. 
G. F. Miller (Müller) — the First Archaeologist in Russia and the First Rector of Saint Petersburg University

\section{The first steps of archaeology in Russia}

A peculiarity of the formation of Russian archaeology is the fact that before the beginning of the 18th century there was no antiquarianism in Russia, such as was important in Europe as a cultural phenomenon. This was partly due to the fact that classical artifacts were not known and were not discovered on its territory until the last quarter of the 18th century. Interest in antiquities originally manifested itself in the collection of rarities and jewels in the princes' and tsars' treasure rooms, and in church vestries. The initial steps of Russian archaeology belong to the era of Peter the Great, although some mentions of the archaeological sites may be found in earlier times. In 1714, the first Russian Museum-Kunstkamera in St. Petersburg-was founded on Peter's orders and acquired a collection of artifacts from the burial mounds of southern Siberia, which he had received as a gift. In 1718 he issued the following decree:

If anyone finds in the soil or in the water any ancient things $[\ldots]$ also any ancient inscriptions on stones, iron or copper things, or some weapons, old and unusual at the present time, dishes and everything else that is old and unusual, [they] have to be brought and [the finder] will be rewarded adequately.

This decree initiated the acquisition of archaeological collections (Tikhonov, 2014, p. 155).

In 1719, on the initiative of Peter I, the first scientific expedition, headed by D. G. Messerschmidt (1685-1735), set out for Siberia. The tasks of the complex expedition included the collection of information about the monuments of antiquity and the collection of the ancient things themselves. The first excavations of burial mounds for cognitive, rather than treasure-seeking, purposes were carried out to find out how pagans arranged their graves in old times. At the end of the expedition, in 1727, descriptions of the journey, diaries, and atlases of drawings and collections of ancient things were passed on to the St. Petersburg Academy of Sciences. A participant of this expedition, the captured Swedish officer Baron von Tabbert (I.-F. Stralenberg) (1676-1747), on his return to his homeland, published the book Das Nord- und ostliche Theil von Europa und Asia (Stralenberg, 1730). The thirteenth chapter of this book was devoted to the monuments of antiquity, which were divided into four classes: (1) graves and grave hills; (2) written signs and hieroglyphs; (3) medals; and (4) obelisks. Grave structures, in their turn, were divided into three types: large earthen burial 
mounds, burial mounds with stone fences, and barrows with a mound of stones. All these materials were thoroughly studied by G. F. Miller in preparation for the second academic expedition to Siberia, which began in 1733.

G. F. Miller examined a vast territory from Yekaterinburg to Yakutsk and collected a grandiose amount of information on the geography, history, ethnography and economy of Siberia. As a professional historian, he paid special attention to collecting of archival materials in local archives. The materials he collected made up a significant scientific archive, known under the name of "Miller's portfolios", which was received in the Russian State Archive of Ancient Acts (F 199, op 1-4; 3,180 items) and the St. Petersburg Branch of the Archive of the Russian Academy of Sciences (F 21, op 1-7; 1,235 items) and has not been fully put into scientific circulation yet.

During the years of participation in the expedition Miller's scientific methods, his manner of working on sources, his fundamental views on the tasks and methods of historical research were developed. Together with Miller, who was the head of the academic research group, the following persons took part in the expedition: astronomer de Lille de la Croyère (1685-1741), naturalist Johann Georg Gmelin (1709-1755), students Stepan Krasheninnikov (1711-1765), Alexei Gorlanov, Fedor Popov, and others. It should be noted that throughout the entire activity of the Academic University, a unique form of teaching students was to involve them in all practical undertakings of the Academy, especially expeditions. Equipped with Miller's instructions for describing peoples and their customs and habits, Krasheninnikov made a trip to Kamchatka. The result of his trip was the famous book devoted to the description of the land of Kamchatka-the first Russian work on ethnography, in which Krasheninnikov brilliantly described the primitive culture, customs, and stone tools of the indigenous population of the extreme Northeast of Eurasia.

Two paragraphs of the instructions received by Miller from the Academy of Sciences directly stated the task of collecting information on antiquities. Therefore, it is not surprising that, in addition to collecting and studying archival materials, Miller also engaged in archaeological research: in 1734 he excavated graves in the Ust-Kamenogorsk fortress to see their internal state and position of bones. But these excavations did not yield anything except horses' and human bones. The information received from the local population that there was no treasure to be found in such barrows, did not discourage the researcher, who believed that they must have had copper and iron products that can serve to explain the history of ancient settlers. 
In addition to excavations, Miller collected information about the archaeological sites from the bugroushchiki ('grave robbers'), who knew well what could be found in burial mounds and in which specific burial mound something can be found. Miller also noted that the peak of the digging occurred at the very beginning of the 18th century, when the barrows on the Tobol, the Irtysh, the Ob and the Yenisei became available to Russian settlers after the termination of the constant raids of nomadic tribes of Kalmyks and Kyrgyz to these territories. He wrote, "I found many more people in Siberia who have been primarily feeding on such work, but in my time no one else went fishing for this business, because all the graves in which treasure could probably be found, had already been dug" (Miller, 1937, p. 524). Many things were acquired by purchase. Several gold items were purchased at the Kolyvano-Voskresenskaya Factory, among them a horseman image. Of considerable interest were bronze pole tops with the images of deer and elk, since on similar pole tops from the Minusinsk region mountain goats were usually depicted (Zavitukhina, 1978, p. 38). In total, the following items purchased by Miller in Siberia and transferred to the Kunstkamera were mentioned in the list:

5 copper idols representing deer images, four of which stand on bell-shaped pedestals, from the graves in the Yenisei steppe ... 4 rub. Various copper burial antiquities from the same steppe, weighing 18 pounds at 40 kopecks per pound ... $7 \mathrm{rub} 20 \mathrm{k}$. A pair of iron stirrups and a musket from the bridle, an item of special curiosity, which were found in the same pits at the Yenisei River ... 50 k. (Radlov, 1894, pp. 125-126)

Some items were lost in the fire of the Kunstkamera in 1747 and only their images, drawn with great accuracy and realism by the artist of the expedition, I. V. Lursenius, have reached us. Due to such a high quality of these drawings, many of the depicted objects can be attributed to and correlated with the existing cultural and chronological periodization (Borisenko \& Khudyakov, 2002, p. 14).

\section{The first classification of burial mounds}

According to the results of the excavations, and even more according to grave robbers' information, a classification of funerary structures was created and five groups were identified, the names of which, probably, were also borrowed from the diggers. 
The first group consisted of mayaki ('lighthouses')—majestic barrows, surrounded on all sides by vertically standing stones. The walls of the grave were also strengthened by stone tiles. In such burial mounds usually one person was buried, less often two. Sometimes beside the main skeleton lay a hill of ash. According to the grave robbers, apart from the main grave under the mound of the mayaki, there were one or two additional graves with a cremation or an inhumation. Among the burial inventory there were objects of gold and silver: dishes and small round vessels, earrings, bracelets, and leather belts with overlaid gold plates. Vessels were always placed at the head. Pottery was divided into two types: small pots with a flat bottom and large ones with a narrow throat.

The second type was classified as slantsy ('slates') — small barrows, entirely covered with tiles. Vertically standing corner stones were absent. The walls and the covering of the grave were constructed from slabs. Burnt human bones were usually found in the graves. Often the graves contained clay vessels.

The third type was soil burial mounds — artificially created hills, arranged at the corners and sometimes on the sides with high slabs. Under the earthen mound there was one to three graves. In each corner of the grave there were wooden posts dug in, which were holding the beams, supporting the overlapping of logs, birch bark and earth. The dead were buried in larch coffins. Of the "jewels", thin quadrangular gold plates were often found in such barrows. The burial inventory was mainly made of bronze.

The fourth type was tvoril'nye kurgany ('creative burial mounds'). A small, almost flat space was fenced by tiles placed on the edge. Inside the fence there was one grave, the walls of which were strengthened with slabs. A single skeleton was accompanied by bronze knives, chisels, spearheads and clay vessels. Gold plaques were also come across, but very rarely.

The fifth type was the 'Kyrgyz graves' — small hillocks built over the grave were poured from earth and stones (Gmelin, 1751-1752, pp. 311-391; Belokobylsky, 1986, pp. 26-27).

Concerning the authorship of this classification in historiography, there was a firm opinion that it had been created by I. G. Gmelin. This was also mentioned by Y. G. Belokobylsky (1986, p. 26), G. S. Lebedev (1992, p. 57), and V.I. Matyushchenko (2001, p. 17). The origin of this thesis is quite understandablethis classification was first given to the world by Gmelin in his four-volume Journey through Siberia, published in the early 1750s in Göttingen, Germany (Gmelin, 1752, pp. 311-319). However, for some reason no one paid attention 


\section{G. F. Miller (Müller) — the First Archaeologist in Russia}

and the First Rector of Saint Petersburg University

to the fact that it occurs in the instructions of G. F. Miller (paragraphs 30-38), written a decade earlier than Gmelin's Göttingen edition was published. In this regard, it will be appropriate to introduce the opinion of L. P. Belkovets, who studied the heritage of both researchers: "The cooperation of the two scientists was very close. Only this can explain the similarity in the content of some pages of the Journey with the content of some articles written by Miller's hand". She also pointed out the error of V. V. Radlov and then A. I. Andreyev, who believed that the article manuscript 'About ancient graves in the Yenisei steppe', stored in Miller's portfolios, was written by Gmelin, since it was similar to the fragment from the third volume of his Journey, although there is no doubt that it was written by Miller's pen. This "reciprocity" becomes quite understandable, the researcher writes, "if you remember that both authors were talking to the diggers and the local population, both examined the things found in the graves and the shape of the burial mounds, and discussed what they saw" (Belkovets, 1995, p. 95). It is no coincidence that Gmelin, in the introduction to his book, wrote that more detailed information about antiquities should be expected from Miller, whose sphere of interest they belong to. Unfortunately, Miller was one of those researchers, now disappearing, who would rather collect the material than publish it. Except for one article, the rest of Miller's works on the antiquities of Siberia were only issued more than a hundred years after his death, and some remain unpublished until now.

\section{Instruction on archaeological research of 1743}

Miller expounded his experience in the study of archaeological data in the instructions to the junior scientific assistant I. E. Fisher (1697-1771), who was to replace him in the expedition. The entire instruction contained more than 1,300 paragraphs of all kinds of information on the history, ethnography, and geography of Siberia and outlined a further program for a study of this region. A special section, consisting of 100 paragraphs, was devoted to antiquities (Tikhonov, 2003, pp. 230-235). Miller demanded careful study and description of burial mounds and burials: paragraphs 54 to 82 were devoted to issues to be taken into account during excavations. The instruction noted that it was necessary to fix the smallest details, from the construction of the burial mound and the grave to the condition of the bones of people buried there. All of this was to be described in detail, measured and sketched. It was necessary to identify the orientation of the skeletons, the state of things in the grave, the depth of the 
grave pits, the presence of stone or wooden structures. It also mentioned stone tools, and Miller had no doubt that the so-called "thunderbolts" are the tips of arrows and chisels made by ancient people (paras. 90 and 91). This was a very progressive point of view for that time, as they were often interpreted, according to the medieval tradition, as a result of a lightning strike into the ground. Miller wrote that clay vessels should not be left without attention. The instruction mentioned other categories of archaeological sites: fortifications, carvings, rock paintings, ruins of ancient structures, and stone sculptures.

This was the first instruction in Russian science for carrying out archaeological research, far ahead of its time. Moreover, it was compiled solely on the basis of experience, knowledge and common sense of G. F. Miller, since there had been nothing like that in European science. Unfortunately, this instruction remained unclaimed by its addressee Fischer, as well as by the following generations of scientists. Written in German and stored in the Moscow archive, the instruction was forgotten by Russian archaeology and was for the first time published in Russian by V. V. Radlov (1837-1918) only in 1894, when it came to be of rather historiographical interest, since by that time other instructions for carrying out archaeological research had appeared.

\section{The first article on archaeology in Russian}

Miller was one of the first researchers who realized the historical importance of archaeological objects, so he postulated that "the main purpose of studying antiquities is, of course, to serve as an explanation for the ancient history of the inhabitants of the region" (Tikhonov, 2003, p. 230). Proceeding from this postulate, he used the results of archaeological research in his History of Siberia, for example, confirming the thesis about the rich prey captured by the Mongol-Tatars in different countries. Of course, at that time such tasks were only postulated, since scientists had not yet discovered certain ways and methods to solve them. For a long time excavated items had been regarded as curious knick-knacks, but Miller had already considered them in the context of history, and not just a simple land description. Miller related all the burial mounds that he was aware of to the "Tatar era", not realizing their deep ancientry, although he distinguished them from the later Kyrgyz graves. Burials also differed, in his opinion, by the degree of wealth-the further to the east, the poorer (Miller, 1764, p. 488). In December 1764, Miller published an article, devoted 


\section{G. F. Miller (Müller) — the First Archaeologist in Russia}

and the First Rector of Saint Petersburg University

to some antiquities found in the graves, in the scientific journal Monthly Works and News of Academic Affairs, edited by him. He drew attention to the burial, where "everything was made of red copper: knives, daggers, arrows and other things although iron was much more convenient. So the people who buried their departed there were probably unfamiliar with the use of iron. Consequently, these graves are much older than the others" (Müller, 1764, p. 489). Later the same article was published in German (Müller, 1779). It was more than seventy years before the creation of the three-century system of the Danish archaeologist C.-J. Thomsen (1788-1865). However, Miller's knowledge was not in vain: three years after Miller's death, a representative of the next generation of Petersburg academicians, V. F. Zuev (1754-1794), published a textbook in which he claimed that copper had been widespread in ancient times, because "without knowing either cast iron, iron or steel, they made from it [copper] everything that we are now making from them" (Zuev, 1786, p. 43). The pages of this article by G. F. Miller, which can be rightfully considered the first scientific publication on archaeology in Russian, contain other correct and accurate observations. For example, the author noticed that the main occupations of the population of Southern Siberia were raising livestock and hunting, and not farming, or that some burial mounds could be patrimonial tombs where the dead were buried in a common grave.

In the same article Miller describes the famous finds discovered by A. P. Melgunov in the barrow Mold Grave in 1763. It was the first Scythian burial mound in Russia, excavated with scientific, but not treasure-seeking purposes. Gold and silver items found during the excavations were placed at St. Petersburg Kunstkamera, upon the order of Empress Catherine II, and their description was entrusted to Miller. Upon the order of the scientist, colored drawings of the most noteworthy things were made. Having described the finds, he tried to compare them with similar objects found in the Siberian burial mounds. After examining information about the peoples who once inhabited the Black Sea steppes, Miller made a correct conclusion that those things should be "older than the Tatar", and hardly belong to the Polovtsi, Pechenegs or Khazars. He also mentions that the most ancient inhabitants of that area were Sarmatians or Scythians, who traded with Greek colonies. But the absence of antique coins in the burial did not allow attributing the complex to those times. As a result, the scientist came to the conclusion that the burial belongs to "the Ugric people or Hungarians who lived in ancient times on this territory". Moreover, this conclusion was made, as we would now say "archaeologically", on the basis of a certain similarity of a "necklace" and "neck chains" with decorations used 
by descendants of the Finno-Ugric peoples in the 18th century. In the opinion of I. V. Tunkina (1998), such a mistake was fully explained by the novelty of the studied site, the absence of any chronological references and the lack of elaboration of this topic at the time. Indeed, at that time, no one had the slightest idea of the material culture of Scythian tribes. But the academician with amazing intuition caught the eastern influence in the products and ornaments of the Mold Grave (Tunkina, 1998, p. 20). In general, Miller was always very cautious in his ethnogenetic investigations, believing that "it is better to leave the ancient stories about peoples, in the absence of solid evidence, in the darkness, rather than provide false explanations about them". Proceeding from this, he proposed to postpone the final solution of many issues till the time "when more graves will be excavated".

Two more articles by Miller 'On the monuments of the antiquity of the Tatar, found in the burial hills near the Abakan and Sayan fortresses' and 'About ancient monuments in the districts of Selenginsk and Nerchinsk' were discovered by V. V. Radlov and first published in his Siberian Antiquities, and then reprinted in both editions of Miller's History of Siberia. In addition to these, the manuscripts of the already mentioned article 'About ancient graves in the steppe of the Yenisei River' and, according to N. A. Golitsyn, the article 'Description of old graves in the southern outskirts of Russia' are now held in the archives (Golitsyn, 1899, p. 27).

After moving to Moscow, Miller continued to consult new expeditions of St. Petersburg Academy of Sciences to Siberia, the Volga region, the Urals and the Northern Black Sea coast. They were headed by I. I. Lepekhin (1740-1802), P. S. Pallas (1741-1811), and V. S. Zuyev. Their tasks also included points connected with the study of archaeological sites: "to observe the antiquities encountered, to inspect the ruins and remains of ancient sites" (Tikhonov, 2003, pp. 17-21). Pallas constantly corresponded with Miller and informed him, among other things, about the examined antiquities. Pallas carried out the excavations in Siberia, using the instruction of his predecessor G. F. Miller.

We can state that Miller wrote the first scientific works dedicated specifically to archaeological data, and accordingly this allows us to consider Gerhard Friedrich Miller as the first Russian scientist seriously engaged in the study of archaeology. 


\section{G. F. Miller (Müller) — the First Archaeologist in Russia}

and the First Rector of Saint Petersburg University

\section{The first rector}

Miller made a significant contribution to the development of university education in Russia. On 24 July 1747, Empress Elizabeth approved the Regulations of the Academy of Sciences and Arts in Saint Petersburg. A part of this document was dedicated to the university, which, together with the gymnasium, had belonged under the Academy of Sciences since 1724. The staff list attached to the Regulations established the position of rector of the university, which was supposed to be occupied by an academician-historian. Later, M. V. Lomonosov (1711-1765) spoke ironically about this, "had Miller been a lawyer or a poet, then, of course, a lawyer or a poet would be appointed as rector" (Lomonosov, 1758-1759). On 10 November 1747, the President of the Academy of Sciences formally appointed Miller as rector of the university with a salary of 1,000 rubles a year.

Miller vigorously engaged in university affairs. Since the beginning of the academic year, Baron Stroganov's house, which was located next to the main buildings of the Academy of Sciences on the Spit of Vasilievsky Island, was rented to the university and gymnasium (Kostina, 2013, pp. 8-10). By order of Miller, 3 tables, 36 chairs, and 4 boards were purchased to equip the classrooms. The building was equipped with a physics cabinet for experiments and an anatomy theatre. The number of students who started their studies was 37. In April 1748, the Academy of Sciences approved the catalog of lectures in Latin prepared by Miller. It was planned that lectures would be given on philosophy, mathematics, ancient history, universal history, modern history of European states, oratory and eloquence. Then the students could specialize in astronomy, anatomy and physiology, chemistry, mechanics, and botany. Miller considered it necessary to introduce additional classes in geography and arithmetic, and ensured teaching foreign languages: French and German. He invited his own brother to teach German. He prepared chronological tables on history for students (Smagina, 2010, p. 58).

Miller took his responsibilities very seriously, and at the same time he took care of the students. He even had to take measures against the theft of firewood in order to make sure the students had a sufficient quantity for the winter. He asked to allocate additional 10 rubles a year to each student for the purchase of books. One of the features of the first Russian university that distinguished it from the Western European universities was that all students were financed by the Academy of Sciences. According to the established plan of 1747, each student 
was paid 100 rubles per year. Miller tried to encourage talented and hardworking students, to provide them with the necessary teaching mediums and tools, for example, drawing utensils. He paid much attention to student discipline and developed a system of punishments and penalties for misconduct. For nonattendance of lectures and poor performance, students had to wear a gray coat of coarse cloth. For more serious misconduct, they were put in an isolation cell for up to two weeks and were fed only with bread and water. Miller personally developed the rules of conduct for students. Many of them are applicable at the present time: smoking, alcoholic beverages, gambling were banned. Some rules are slightly outdated, for example, it was forbidden to let a woman even enter the door (Tikhonov, 1997, p. 15).

Most of the students who studied at the university at that time remained to work at the Academy of Sciences later, and many of them-mathematicians S. K. Kotelnikov and M. Sofronov, anatomist A. P. Protasov, astronomer S. Y. Rumovsky-became famous scientists. A. A. Barsov and N. N. Popovsky were among the first professors of the Moscow University, established in 1755.

Miller's particular achievement as rector was the creation of the University Draft Regulations, containing 85 paragraphs. Following the example of European universities, the project provided for autonomy, inner court, the right to award academic degrees and rise of professors in the social status, their exemption from military service and police supervision. Professors had to read for two hours every day and pay a fine for non-attendance without a good reason. Four hours in the morning and three hours in the afternoon were provided for lecturing. This draft paid a lot of attention to the duties of the rector, such as developing education plans and training agendas, holding examinations for applicants, keeping a list of students (matricula), establishing penalties, etc. (Hoffman \& Smagina, 2002, pp. 419-437).

Consideration of this draft at the Academy of Sciences took place from August 1748 to January 1750 and provoked heated discussions with the participation of M. V. Lomonosov, V. K. Trediakovsky, I. A. Braun, H. Krusius and other professors and academicians. Lomonosov believed that the draft did not sufficiently reflect the structure of the university, which should have consisted of three faculties and the rector. He proposed to divide the education into three classes (levels). The first-year students would need to attend all lectures, the second-year students-only those in their science area, and the thirdyear students-only those given by one professor. Miller's draft was greatly criticized by the adviser to the Academic Chancellery I. D. Schumacher. As a 
result, this draft of university regulation was not approved, and in June 1750, Miller was dismissed from the position of rector. A student of Miller, Stepan Krasheninnikov was appointed as the new rector of the university.

One of the reasons for Miller's dismissal was his speech presented in 1749 in Latin On the Origin of People and the Russian Name, which provoked sharp criticism from M. V. Lomonosov, who accused Miller of political mistakes and considered this work offensive to the glory of Russian people (Klejn, 2009, pp. 15-24). Lomonosov especially objected to Miller's attempts to link the origin of the name 'Rus' with the Finnish name of the Swedes 'Ruotsi'. Lomonosov himself believed it to derive from the 'Roxolans' or 'Rossolans' who moved to the Baltic region. Such view was quite in line with the influential concept of European science in the 17th-18th centuries. Subsequently, Miller himself was forced to join it. In their disputes, two points of view on the tasks of history were demonstrated. Lomonosov believed that history needed to serve the interests of the state, and Miller said that a historian did not need to have a king, religion or fatherland. As a result, in October 1750, Miller's work was banned, and he was demoted to a position with a lower salary. However, three months later he regained his former title of professor and former salary.

Having moved to Moscow, Miller, using his experience of university management in St. Petersburg, continued to take part in the work of the Commission for Public Education, established by Empress Catherine II in 1763. In 1765, he prepared a project for the transformation of the Moscow University. The main idea of the project was that the university would more successfully perform in its main function, according to Miller-the raising of scientists (Serdyutskaya, 2008).

\section{Conclusion}

It should be noted that Gerhard Friedrich Miller was an outstanding figure in the European and Russian Enlightenment of the 18th century who made a great contribution to the establishment of Russian archaeology and the first Russian university. He wrote the first scientific works on antiquities in Russia. Having become the first rector of St. Petersburg University, he tried to establish a normal course of study and give it a semblance of European universities. 


\section{References}

Belkovets, L. P. (1990), Johann Georg Gmelin: 1709-1755, Moscow: Nauka.

Belokobylsky, Y. G. (1986), Bronzovyj i rannij zheleznyj vek Iuzhnoj Sibiri. Istorija idej i issledovanij (XVIII - pervaja tret'XX v. [The Bronze and Early Iron Age of Southern Siberia. History of ideas and research (18th to the first third of the 20th century] Novosibirsk: Nauka, Sib. Otd.

Black, J. L. (1986), G.-F. Müller and the imperial Russian Academy, Kingston: McGillQueen's University Press.

Borisenko, A. Y. \& Khudyakov, Y. S. (2002), 'Vklad Ioganna Vilgel'ma Lurseniusa $\mathrm{v}$ izucheniie drevnostei Yuzhnoi Sibiri' [The contribution of Johann Wilhelm Lürsenius to the study of the antiquities of Southern Siberia], in A. S. Mylnikov \& T. A. Shrader (eds.) Nemtsy v Sankt-Peterburge, (XVIII-XX veka): biograficheskij aspekt $=$ Deutsche in Sankt Petersburg. Das 18-20. Jh (biographisches Aspekt), Materials of the ongoing conference, no. 2, St. Petersburg, pp. 12-18.

Dalmann, D. \& Smagina, G. I., eds. (2007), Gerard Fridrikh Miller i russkaia kultura [Gerard Friedrich Miller and Russian culture], St. Petersburg: Rostok.

Dvornichenko, A. Y. (2005), G. F. Miller i rossiiskaia istoricheskaia nauka [G. F. Miller and Russian historical science], in Sankt-Peterburgskii Universitet, nos. 24-25, pp. 21-24.

Elert, A. Kh. (1996), Sibir' XVIII veka v putevyh opisaniiakh G. F. Millera [Siberia of the 18 th century in the traveler's descriptions of G. F. Miller], Novosibirsk: Sibirskii Khronograf.

Gmelin, I. G. (1752), Reise durch Sibirien von dem Jahre 1733 bis 1743, Th. 3, Göttingen: Abram Vandenhoecks seel. Wittwe.

Golitsyn, N. V. (1899), Portfeli Millera [Miller's portfolios], Moscow: Tip. G. Lissner \& A. Geshel.

Hoffmann, P. (2005), Gerhard Friedrich Müller (1705-1783): Historiker, Geograph, Archivar im Dienste Russlands, Frankfurt am Main: Peter Lang. https://doi.org/10.7788/boehlau.9783412328658.419

Hoffman, P. \& Smagina, G. I. (2002), 'Zur Frühgeschichte der Universitätsausbildung in Russland. Gerhard Friedrich Müllers "Vorschlag zu einem Reglement für Universität bei der Kaiserliche Akademie der Wissenschaften” vom 1748,' in E. Donnert (ed.) Europa in der frühen Neuzeit, Bd. 6, Köln, Weimar \& Wien: Böhlau Verlag, pp. 419-437.

Ilizarov, S. S. (2005), Gerard Fridrikh Miller (1705-1783) [Gerard Friedrich Miller (1705-1783)], Moscow: Janus-K.

Klejn, L. S. (2009), Spor o variagakh. Istorija protivostoyaniia i argumentyi storon. [Dispute about the Varangian. History of confrontation and arguments of the parties], St. Petersburg: Evrazia. 
G. F. Miller (Müller)—the First Archaeologist in Russia and the First Rector of Saint Petersburg University

Kostina, T. V. (2013), Prostranstvo akademicheskih gimnazii $i$ universiteta: Materialy $k$ istorii. 1724-1895 gg. [The space of academic gymnasium and university: materials on history. 1724-1895], KLIO, no. 10 (82), pp. 6-15.

Lebedev, G. S. (1992), Istoriia otechestvennoi arkheologii, 1700-1917 gg. [History of Russian archaeology 1700-1917], St. Petersburg: Izdatelstvo Sankt-Peterburgskogo Universiteta.

Lomonosov, M. V. (1758-1759), Zapiska o neobhodimosti preobrazovanija Akademii nauk [Note on the need to transform the Academy of Sciences]. Retrieved from http://drevlit.ru/docs/russia/XVIII/1740-1760/Lomonosov/IP/Tom_II/ Zapiska_o_preobr_AN/text.php [accessed May 2018]

Matyushchenko, V. I. (2001), Trista let istorii sibirskoi arkheologii [Three hundred years of the history of Siberian archaeology], Omsk: Omskii Gosudarstvennyi Universitet.

Miller, G. F. (1764), Iziasnenie o nekotorykh drevnostiakh v mogilakh naidennykh [An explanation of some antiquities found in the graves], in Ezhemesiachnye sochineniia i izvestiia ob uchenykh delakh, December, pp. 483-515.

Miller, G. F. (1937), Istoriia Sibiri [History of Siberia], Moscow \& Leningrad: Izdatelstvo AN SSSR.

Müller, G. F. (1732-1764), Sammlung russischer Geschichte, St. Petersburg: Bey der Kaiserl. Academie der Wissenschafften.

Müller, G. F. (1779), 'Von den alten Graebern in Sibirien und Neurussland,' St. Petersburgisches Journal, vol. 8 (Julius), pp. 3-29.

Radlov, V.V. (1994), Sibirskiie drevnosti [Siberian antiquities], vol. 1, no. 3, St. Petersburg.

Serdyutskaya, O. V. (2008), "'Mysli ob uchrezhdenii Moskovskogo universiteta..." G. F. Millera kak odin iz proektov preobrazovanija universiteta. 1765 g.' ["Thoughts on the Establishment of the Moscow University...": G. F. Miller as one of the university's transformation projects. 1765], Otechestvennyje arkhivy, no. 4, pp. 57-65.

Smagina, G. I. (2010), Akademiia nauk i zarozhdenie universitetskogo obrazovaniia $\mathrm{v}$ Rossii [Academy of Sciences and the origin of university education in Russia], in Zh. I. Alferov (ed.) Akademiia nauk v istorii kul'ture Rossii, St. Petersburg: Nauka, pp. 39-80.

Stralenberg, P. J. (1730), Das Nord- und ostliche Theil von Europa und Asia: In so weit solches das gantze russische Reich mit Siberien u. der grossen Tatarey in sich begreiffet, in einer historisch-geogr. Beschreibung der alten u. neuern Zeiten, u. vielen andern unbekannten Nachrichten vorgestellet, nebst einer noch niemahls ans Licht gegebenen Tabula Polyglotta von zwey u. dreyssigertey Arten Tatarische Volcker Sprachen u. einem Kalmuckischen Vocabulario,_Sonderlich aber Einer grossen richtigen Land-Charte von den benannten Ländern und andern verschiedenen Kupfferstichen, so die AsiatischScythische Antiquität betreffen; Bey Gelegenheit der Schwedischen Kriegs-Gefangenschaft in Rußland, aus eigener sorgfältigen Erkundigung, auf denen verstatteten weiten Reisen zusammen gebracht und ausgefertiget, Stockholm: Verlegung des Autoris. 
Tikhonov, I. L. (1997), 'Pervyj rektor' [First rector] in Sankt-Peterburgskii Universitet, no. 5 (March), pp. 14-15.

Tikhonov, I. L. (2003), Arkheologiia v Sankt-Peterburgskom universitete. Istoriograficheskiie ocherki [Archaeology at St. Petersburg University. Historiographical essays], St. Petersburg: Izdatelstvo Sankt-Peterburgskogo Universiteta.

Tikhonov, I. L. (2014), 'Chapter 9: Russia,' in P. Bahn (ed.) The History of Archaeology: An Introduction, Abingdon: Routledge, pp. 155-176.

Tunkina, I. V. (1998), Pervyi issledovatel skifskikh kurganov. K biografii A. P. Melgunova (1722-1788) [First researcher of Scythian mounds. To the biography of A. P. Melugunov (1722-1788)], in A. A. Formozov \& I. S. Kamenetsky (eds.) Ocherki istorii otechestvennoi arkheologii, no. II, Moscow: Bogorodskii pechatnik, pp. 12-26.

Vermeulen, H. F. (2018), 'Gerhard Friedrich Müller and the genesis of ethnography in Siberia,' Etnografia, vol. 2018 (1), pp. 40-63.

https://doi.org/10.31250/2618-8600-2018-1-40-63

Zavitukhina, M. P. (1978), Kollektsiia G. F. Millera iz Sibiri-odno iz drevneishikh arkheologicheskikh sobranii Rossii [G. F. Miller's collection from Siberia is one of the oldest archaeological collections in Russia], in Soobscheniia Gosudarstvennogo Ermitazha, no. 43, Leningrad: Avrora, pp. 37-40. Retrieved from http://kronk.spb. ru/library/zavituhina-mp-1978.htm 25/02/2018 [accessed May 2018]

Zuev, V. F. (1786), Nachertanie estestvennoi istorii, izdannoe dlia narodnykh uchilisch Rossiiskoi imperii po vysochaishemu poveleniiu tsarstvuiushchiia imperatritsy Ekateriny Vtoryia [The Inscription of Natural History, published for folk colleges of the Russian Empire by the highest order of the reigning Empress Catherine II], St. Petersburg: Tipografiia Braitkopfa.

Igor L. Tikhonov, PhD (1993), Doctor of History (2013), head of the University History Museum and a professor in the Department of Archaeology at the St. Petersburg State University. His major research areas are history of archaeology and history of universities. He has published several books and more than 200 articles on these topics in Russian and articles in English, French, and Spanish in Antiquity, The History of Archaeology: An Introduction (ed. by Paul Bahn), Etudes de Lettres Lausanne, Trabajos de Prehistoria, etc. 